\title{
Step Up DC-DC Converter based on Three Winding Coupling Inductor
}

\author{
R. Ramya, Sushmita Gupta, S. Usha, \\ Pavitra Chopperla, A. Sriram
}

\begin{abstract}
This paper presents the new topology for DC-DC converter based on three winding coupled inductor that boosts the voltage. This topology includes high frequency coupled inductor and voltage multiplier cells[1]. The main aim is to increase the voltage gain. The output voltage is clamped across the capacitor of Voltage Multiplier Cells (VMC). Only one active switch is used which is MOSFET. The voltage stress is decreased and overall efficiency is been improved. The quantity of diodes can be diminished by expanding the quantity of auxiliary windings of coupling inductor. The spillage inductance of the coupled inductor is reused by exchanging capacitor and can be straightforwardly exchanged to stack.
\end{abstract}

Keywords--- Active Switch, Voltage Multiplier Cells (VMC), CUK Converter, Leakage Inductance, Switch Voltage Stress.

\section{INTRODUCTION}

DC-DC converters with voltage help ability are broadly utilized in countless transformation applications, from division of-volt to many thousands.

The basic boost converter with unlimited voltage gain is a preferable candidate, but the higher voltage gain will use the higher duty cycle ratio, which will result in many serious problems such as the reverse-recovery of diodes, higher losses, and higher voltage stress across passive components.[1,3] Boost converters in series are presented to realize the higher voltage gain, but these results in complicated systems and influences reliability due to the presence of additional switches and control units.[2]

Quadratic boost converters based on cascaded technology can improve voltage gain and are applied extensively, but two switches and control circuits in quadratic boost converters increase the complexity and cost of systems, and the voltage gain still needs to be improved to meet many application circumstances. Some DC-DC converters with coupled-inductor cells are presented to realize higher voltage gains[3]. $\operatorname{In}[4]$, the converter gain is achieved via a switched capacitor, but this increases the conduction loss and reduces efficiency. The voltage gain of this converter was extend by switched inductor technology however, the voltage stress on the switches will stay at a high level, and thus, the active switches induce serious conduction losses. A voltage lift technique has been proposed. By the voltagedouble capacitor, the voltage-boost ability is increased; unfortunately, the capacitor will suffer high voltage and

Revised Version Manuscript Received on August 19, 2019.

R. Ramya, Assistant Professor, Department of Electrical and Electronics, SRM Institute of Science and Technology, Chennai, T.N, India

Sushmita Gupta, UG Research Scholar, Department of Electrical and Electronics, SRM Institute of Science and Technology, Chennai, T.N, India

S. Usha, Assistant Professor, Department of Electrical and Electronics, SRM Institute of Science and Technology, Chennai, T.N, India

Pavitra Chopperla, UG Research Scholar, Department of Electrical and Electronics, SRM Institute of Science and Technology, Chennai, T.N India

A. Sriram, UG Research Scholar, Department of Electrical and Electronics, SRM Institute of Science and Technology, Chennai, T.N, India current stresses. The switched capacitor and switched inductor technique are used to realize high step-up voltage gains, but they lead to larger power losses[2,4].

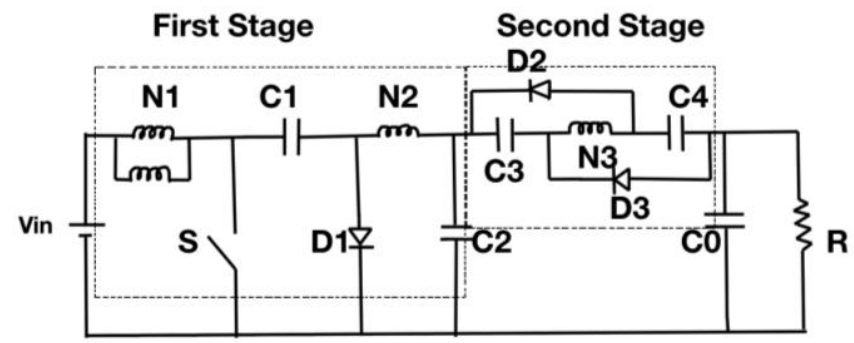

Fig.1: Proposed Topology for DC-DC Converter

The improved coupled inductor DC-DC converters with two winding and three winding coupled-inductor cells are presented to realize higher voltage gains, but the switches are placed at the output diode to higher switch voltage stresses. By adjusting the turn ratio of a coupled inductor, the converter can obtain a high step-up voltage gain but, on the down side, the leakage inductor will cause a high voltage spike on the active switches. To resolve this weakness, an active clamp circuit is presented. However, the active clamp circuit does not achieve the step-up voltage, reduces efficiency, and adds extra cost. The converter can recycle the energy of the leakage inductor and improve the performance by using a negative clamp circuit to increase efficiency[4].

In this paper, a novel high step-up converter with a smaller turn ratio is proposed, and can achieve higher gain through coupled inductor technology and voltage lift technology, which will be beneficial to connect the power grid and transmit renewable energy under broader application circumstances. The inactive lossless braced circuits not exclusively can retain the spillage vitality, yet in addition bring down the switch voltage stresses; furthermore, the turn around recuperation issue of diodes can be diminished to improve the framework effectiveness. Furthermore, the voltage worry of the yield capacitor is decreased. The working standard and comparing hypothetical investigations are examined in detail.

\section{OPERATION PRINCIPLE AND PARAMETER CALCULATION}

The circuit consist of DC input voltage $\mathrm{V}_{\text {in, }}$ one active switch $\mathrm{S}$, five capacitors $\mathrm{C}_{1}, \mathrm{C}_{2}, \mathrm{C}_{3}, \mathrm{C}_{4}$ and $\mathrm{C}_{5}$, coupled inductor which has primary winding, secondary, tertiary winding and a magnetizing inductance $\mathrm{L}_{\mathrm{m}}$ and three diodes $D_{1}, D_{2}$ and $D_{3}$ have been used. This circuit can be divided into two stages which is shown in Fig.1.

Published By:

Blue Eyes Intelligence Engineering

\& Sciences Publication

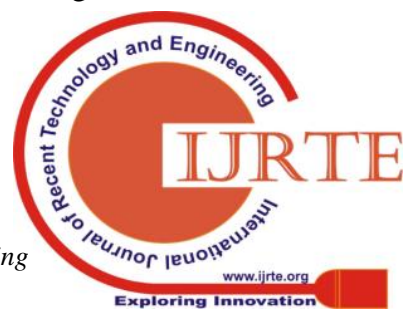


The first stage consists of CUK circuit with one diode $D_{1}$, capacitors $C_{1}, C_{2}$, and inductor $L_{1}$ and $L_{2}$. The second stage consists of voltage multiplier cells (VMC) with two capacitors $\mathrm{C}_{3}, \mathrm{C}_{4}$, Diodes $\mathrm{D}_{1}$ and $\mathrm{D}_{2}$ and output capacitor $\mathrm{C}_{5}$. The primary inductor has $\mathrm{N}_{1}$ turns and secondary inductor has $\mathrm{N}_{2}$, and tertiary inductor has $\mathrm{N}_{3}$ turn. Therefore coupled inductor ratio will be $\mathrm{N}_{21}=\mathrm{N}_{2} / \mathrm{N}_{1}$ and $\mathrm{N}_{31}=\mathrm{N}_{3} / \mathrm{N}_{1}$.

The coupled inductor stores the energy and act as a transfer device. The main waveform of performance of several components are shown in Fig. 2 and an operating mode with current direction in circuit is shown in Fig.3.

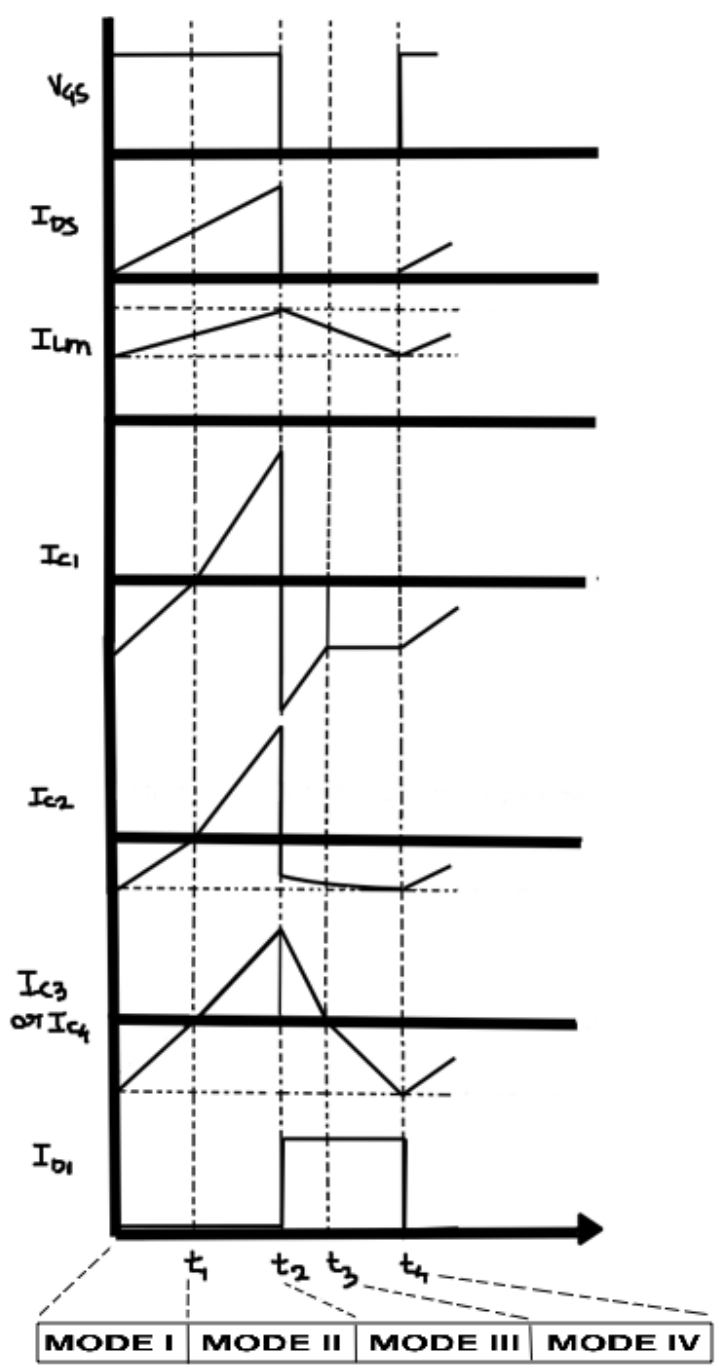

Fig.2: Main waveforms

Mode I $[\mathrm{t} 0<\mathrm{t}<\mathrm{t} 1]$ : In this mode, the dynamic switch $\mathrm{S}$, diodes D2 and D3 are in turned on state and diode D1 is in killed state. The DC input voltage source stores vitality in the polarizing inductor $\mathrm{Lm}$ and the capacitor $\mathrm{C} 3$ and $\mathrm{C} 4$ are getting charge from optional winding N3. The capacitor C1 and $\mathrm{C} 2$ are getting released. The yield capacitor gives vitality to the heap. The present heading is appeared. This mode closes at $\mathrm{t}=\mathrm{t} 1$.

Mode II $[\mathrm{t} 1<\mathrm{t}<\mathrm{t} 2]$ : Switch $\mathrm{S}$ is still in on state in this mode. Amid this mode the polarizing inductor current ILm achieves most extreme current. The capacitor C1 C2 still proceed to release and capacitor $\mathrm{C} 3$ and $\mathrm{C} 4$ are as yet getting charged. The diode D1 is killed and diodes D2 and D3 are as yet leading when the turn is killed.
Mode III [ $\mathrm{t} 2<\mathrm{t}<\mathrm{t} 3$ ]: In this mode diode D1 is exchanged on and the diodes D2 and D3 turn off. Amid this mode, the present charges toward the capacitor $\mathrm{C} 1$ and $\mathrm{C} 2$. The DC input voltage is in arrangement with the inductor $\mathrm{L}$, capacitor $\mathrm{C}$ and is moving through diode. The heap is in arrangement with the capacitor $\mathrm{C} 3$ and $\mathrm{C} 2$. The yield capacitor is getting charged. This mode closes at $\mathrm{t}=\mathrm{t} 3$. The working mode is appeared in Fig.3.

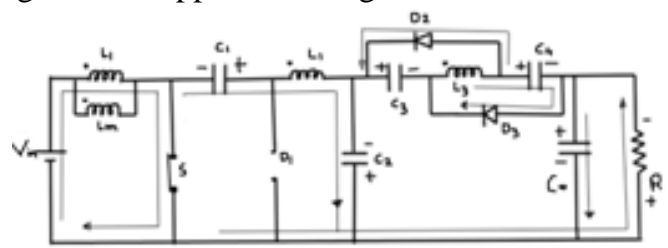

(a) $\left[t_{0} \sim t_{1}\right]$ MODE I

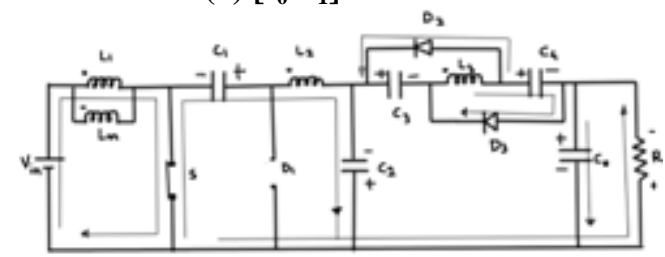

(b) $\left[\mathbf{t}_{1} \sim \mathbf{t}_{2}\right]$ MODE II

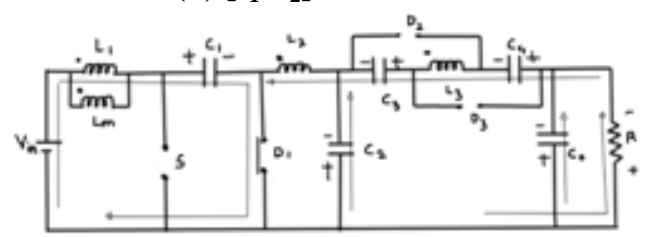

(c) $\left[t_{2} \sim t_{3}\right]$ MODE III

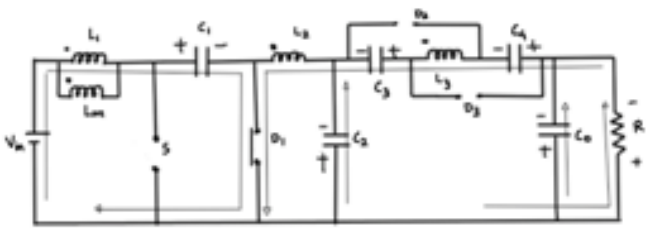

(d) $\left[\mathbf{t}_{3} \sim \mathbf{t}_{4}\right]$ MODE IV

Fig.3: Operating modes

Mode IV [t3<t<t4]: In this mode the dynamic switch $\mathrm{S}$, the diodes D2 and D3 are still killed and diode D1 is turned on. The capacitor $\mathrm{C} 1$ and $\mathrm{C} 2$ are released which is associated in arrangement with the heap, inductor L2 and L3.This mode closes when the switch is turned on again.

For given formula of CUK circuit

$$
\mathrm{V}_{0} / \mathrm{V}_{\text {in }}=-\mathrm{d} /(1-\mathrm{d})
$$

, where $\mathrm{d}$ is the one cycle period where the switch is turned-on.

Hence, for this circuit output voltage in CCM operation mode be

$$
\begin{gathered}
\mathrm{V}_{\mathrm{c} 2}+\mathrm{V}_{\text {in }}+2 \mathrm{~N}_{21} \mathrm{~V}_{\mathrm{L} 1}+\mathrm{N}_{21} \mathrm{~V}_{\text {in }}=0 \\
\mathrm{~V}_{\mathrm{C} 2} / \mathrm{V}_{\text {in }}=-\left(2+2 \mathrm{~N}_{21}+\mathrm{d}\right) /(1-\mathrm{d}) \\
\mathrm{V}_{\mathrm{C} 5}+\left(\mathrm{V}_{31} / 2\right)-\mathrm{V}_{\text {in }} \mathrm{N}_{31}+\mathrm{V}_{0}=0 \\
\mathrm{~K}=1 / 2 \\
\mathrm{~V}_{\mathrm{C} 5}=(-\mathrm{KN} 31+\mathrm{Dn} 31) /(1-\mathrm{d})
\end{gathered}
$$

Hence, adding (1) and (2) we will get output voltage for this circuit 


$$
\begin{gathered}
\mathrm{M}_{\mathrm{CCM}} \mathrm{V}_{0} / \mathrm{V}_{\text {in }}=\mathrm{V}_{\mathrm{C} 2} / \mathrm{V}_{\text {in }}+\mathrm{V}_{\mathrm{C5}} / \mathrm{V}_{\text {in }} \\
=-\left(2+2 \mathrm{~N}_{21}+\mathrm{d}-\mathrm{KN}_{31}+\mathrm{dN}_{31}\right) /(1-\mathrm{d})
\end{gathered}
$$

\section{SIMULATION \& RESULTS}

The operation of this circuit was analysis MATLAB simulation and circuit is been shown in Fig.4, where the output voltage is $171 \mathrm{~V}$ and a power of $292 \mathrm{~W}$ at a duty cycle of 60 and a frequency of $50 \mathrm{kHz}$ and voltage stress at the switch was seen $10.26 \mathrm{~V}$. The result are plotted in shown in TABLE 1 and the respected graph is also shown in Fig.5. In this number of component are been reduced.

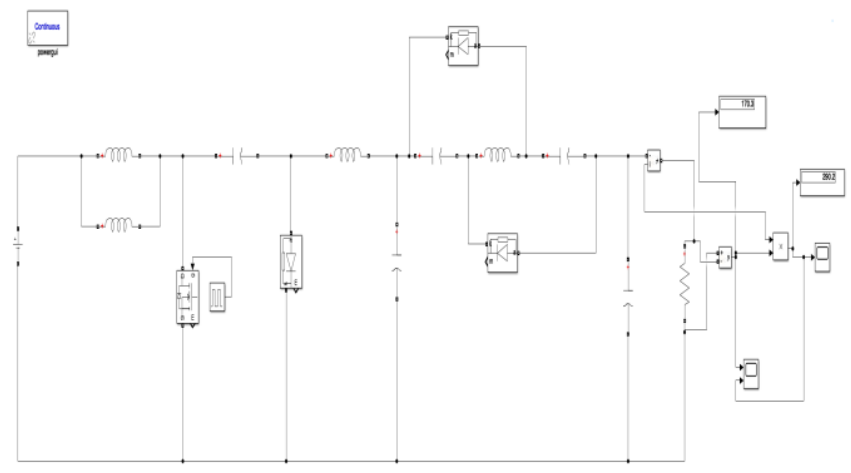

Fig. 4: Simulation Circuit

For different duty cycles, the voltage stress of the switch $\mathrm{S}$ is been shown in TABLE 2 and the graph is also shown in Fig.6. As seen that with an increase in duty cycle the voltage across the active switch also increases hence in practical we will not be keep high duty cycle.

Table 1: Parameters of DC-DC Converter

\begin{tabular}{cc}
\hline Parameters & $\begin{array}{c}\text { Developed Step Up } \\
\text { DC-DC Converter }\end{array}$ \\
\hline $\begin{array}{c}\text { Coupled inductor } \\
\text { Turn Ratio } \\
\text { Input, Vin }\end{array}$ & $1: 2: 2$ \\
Output, Vout & $10 \mathrm{~V}$ \\
Power & $171 \mathrm{~V}$ \\
Duty Cycle, d & $291.4 \mathrm{~W}$ \\
Switching & 0.6 \\
frequency & $50 \mathrm{kHz}$ \\
Load & $100 \mathrm{Ohm}$ \\
\hline
\end{tabular}

Table 2: Voltage stress of switch at different duty cycle

\begin{tabular}{cc}
\hline Duty cycle & $\begin{array}{c}\text { Voltage stress of } \\
\text { switch }\end{array}$ \\
\hline 0.1 & $9.73 \mathrm{~V}$ \\
0.2 & $9.89 \mathrm{~V}$ \\
0.3 & $10.02 \mathrm{~V}$ \\
0.4 & $10.09 \mathrm{~V}$ \\
0.5 & $10.18 \mathrm{~V}$ \\
0.6 & $10.26 \mathrm{~V}$ \\
0.7 & $10.28 \mathrm{~V}$ \\
0.8 & $10.32 \mathrm{~V}$ \\
0.9 & $10.37 \mathrm{~V}$ \\
\hline
\end{tabular}

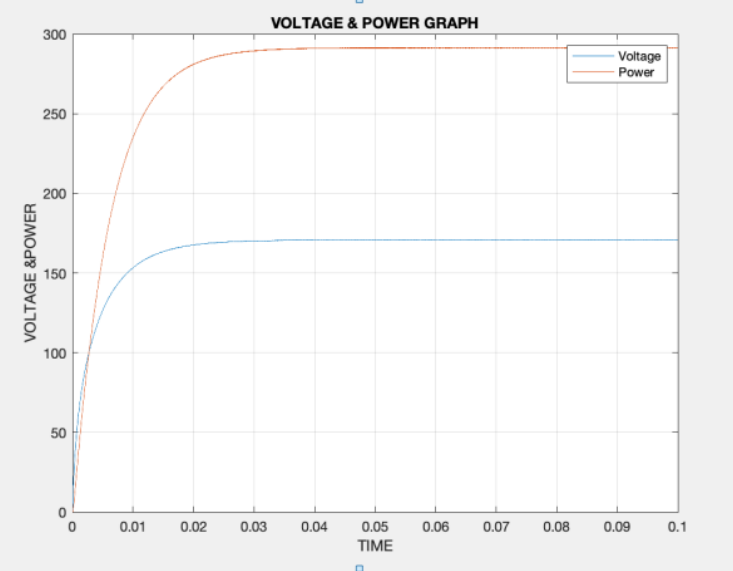

Fig.5: Response of Voltage and Power graph

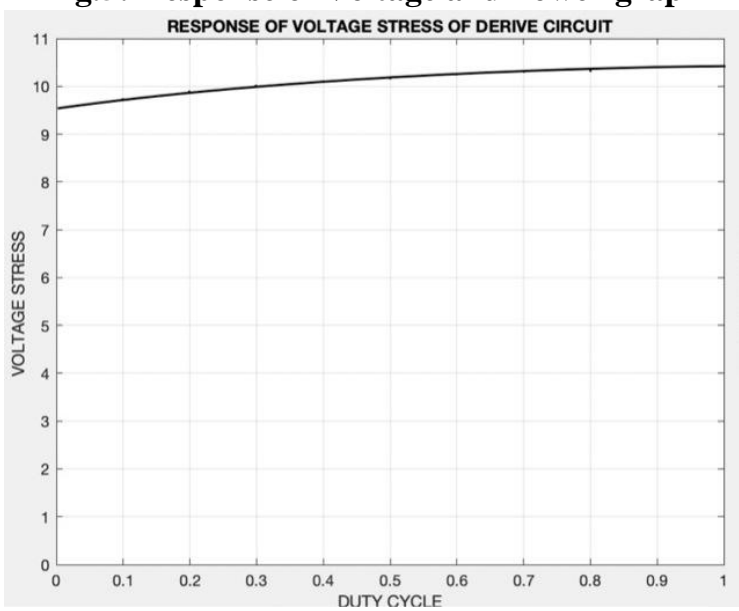

Fig.6: Response of Output Voltage stress at different cycle

\section{CONCLUSION}

In this paper, a stage up DC-DC converter utilizing three twisting high-recurrence coupling inductor and a voltage multiplier cell is utilized to expand the voltage at the yield. Utilizing a solitary dynamic switch, voltage stress is decreased and the effectiveness of the circuit is improved in correlation with reference[2]. The benefit of this circuit gives a smooth output in comparison with available literature. The wastage of inductance leakage can be reduced by switching the capacitors and directly transferring it to the load. Experimental validation for this work can be carried out further as a future scope. Recycling energy of magnetizing inductor which is given to the load is in the release manner and different duty cycles are been simulated. The key parameter is been closure in this and has been identified and discussed and their importance are been ensured that they aim and objectives in the improvement of DC-DC converter.

\section{REFERENCES}

1. Abbas A.Fardoun and Esam H.Ismail, "Ultra Step-Up Dc-Dc converter adopting switching-capacitor cell” IEEE Trans.ind.Appl.,vol.46,no.5,pp.105-133, Oct 2010.

2. S. M. Salehi, S. M. Dehghan, S. Hasanzadeh, " Ultra step-up DC-DC converter based on three windings coupled inductor" IEEE 2016 7th Power Electronis and Drive System Technologies Conference(PEDSTC) 01September 2016. 
3. Gang Wu, Xinbo Ruan, Zhihong Ye, "Non-Isolated high Step-Up Converter Adopting Coupled Inductor" IEEE Trans.Ind.Electron, in press.

4. Tsai-Jie Lin, Jiann-Fuh Chen,"A novel high step-up DC-DC converter with coupled-inductor" Yi-Ping Hsieh 2013 1st International Future Energy Electronics Conference (IFEEC) 19 December 2013.

5. Markus Pollak, Loreto Mateu, Peter Spies,“ Step-up DC-DC converter based on three windings coupled inductor for low input voltages" Proceedings of Power MEMS 2008+ microEMS 2008, Sendai, Japan, November 9-12, (2008)

6. Markus pollak, Loreto Mateu, Peter Spies, “Step up DC-DC converter with coupled Inductors for low Input Voltages" Proceeding of Power MEMS 2008+ microEMS 2008, Sendai, Japan, November 9-12 (2008).

7. D. Maksimovic and S. Cuk, "Switching converters with wide DC conversion range," IEEE Trans. Power Electron., vol. 6, no. 1, pp. 151157, Jan. 1991.

8. R. Watson, F. C. Lee, and G. C. Hua, "Utilization of an active-clamp circuit to achieve soft switching in flyback converters," in Conf. Rec IEEE Power Electron. Spec., 1994, pp. 909-916.

9. Q. Zhao and F. C. Lee, "High performance coupled-inductor DC-DC converters," in Conf. Rec. IEEE Appl. Power Electron. Conf., 2003 , vol. 1, pp. 109-113.

10. D. Zhou, A. Pietkiewicz, and S. Cuk, "A three-switch high-voltage converter," IEEE Trans. Power Electron., vol. 14, no. 1, pp. 177-183, Jan. 1999.

11. J. W. Baek, M. H. Ryoo, T. J. Kim, D. W. Yoo, and J. S. Kim, "High boost converter using voltage multiplier," in Proc. IEEE IECON, Nov. 2005, pp. 567-572.

12. T. J. Liang and K. C. Tseng, "Novel high-efficiency step-up converter," Proc. Inst. Elect. Power Appl., vol. 151, no. 2, pp. 182190, Mar. 2004.

13. M. Prudente, L. L. Pfitscher, G. Emmenderfer, E. F. Romaneli, and R. Gules, "Voltage multiplier cells applied to non-isolated DC-DC converters," IEEE Trans. Power Electron., vol. 23, no. 2, pp. 871-887, Mar. 2008.

14. B. Axelrod, Y. Berkovich, and A. Ioinovici, "Hybrid switchedcapacitor Cuk/Zeta/SEPIC converters in step-up mode," in Conf. Rec. IEEE Int. Symp. Circuits Syst., 2005, pp. 1310-1313. 